A. Human Rights and Procedural Law 
https://doi.org/10.5771/9783748923503-13

Generiert durch IP '172.22.53.54', am 26.04.2023, 05:04:06. 


\title{
Protecting Human Rights Through Criminal Law: The Revival of the Procedural Obligations
}

\author{
Jacopo Roberti di Sarsina / Katharina Braun ${ }^{1}$
}

\section{A. Introduction}

Human rights protect from an overreach of criminal law, but they also require protection through criminal law. To borrow from Judge Françoise Tulkens, human rights have 'both a defensive and an offensive role, a role of both neutralizing and triggering the criminal law.'2 This article is focused on the 'offensive role' of human rights, i.e., the triggering of criminal law in the jurisprudence of the European Court of Human Rights ('ECtHR' or 'the Court').

In order to ensure enjoyment of the rights recognised in the European Convention on Human Rights ('ECHR' or 'the Convention') infringements upon them - be it through State officials or private individuals must be effectively deterred. How can the Court fight impunity without overstepping its mandate and becoming a criminal court? In its jurisprudence, the Court has to balance between an overly extensive approach to criminal law that could be perceived as interfering with State's sovereignty and an unduly restrictive approach allowing human rights violations to go unpunished. This article focuses on the dichotomy between calls for effective criminal prosecution of human rights violations and the risk of overreach of the Court into the area of domestic criminal law.

The jurisprudence of the ECtHR with regard to criminal law measures has already been analysed in depth. ${ }^{3}$ Contributions have also focused on

1 Dr Jacopo Roberti di Sarsina, LL.M. (New York University), Member of the Legal Service (CFSP and External Relations Team), European Commission. Katharina Braun, LL.M. (University of Connecticut), doctoral candidate at Freie Universität Berlin. The views expressed in this article are those of the authors and may not in any circumstances be regarded as stating an official position of the European Commission.

2 Tulkens, 'The Paradoxical Relationship between Criminal Law and Human Rights' (2011), 9 JICJ, 577 (579).

3 Mallinder, 'Investigations, Prosecutions and Amnesties under Articles $2 \& 3$ of the European Convention on Human Rights' (2015) Transitional Justice Institute, Re- 
the issue of amnesties, which will not be discussed at length here. ${ }^{4}$ Instead, this article centres on the most recent cases and developments regarding the obligations to criminalise, investigate, and prosecute infringements of Article 2 ('right to life') and, to a lesser extent, Article 3 ('prohibition of torture') of the ECHR. Particular attention is paid to a category of cases that has so far received little attention, namely cases arising from unintentional infringements of the right to life. This issue was raised and problematised most recently in February 2020 by Judges Paulo Pinto de Albuquerque and María Elósegui in their joint concurring opinion in Vovk and Bogdanov v. Russia, where they questioned whether the Court's approach to criminal law measures in cases arising from the unintentional infliction of death or life-threatening injuries is consistent with international law and its long-established jurisprudence. ${ }^{5}$ This article also addresses the criticism of the Court's involvement with criminal law and examines the rationales behind the Court's demand for criminal law measures. It concludes that a proactive approach by the Court with regard to criminal law measures is needed in order to ensure the protection of the rights recognised in the ECHR but this would require the Court to better define its role in the interplay between international human rights law and criminal law.

search Paper No. 15-05, https://papers.ssrn.com/sol3/papers.cfm?abstract_id=26681 06; Schabas, The European Convention on Human Rights: A Commentary (2015), 134 ff.; Jackson, 'Amnesties in Strasbourg' (2018) 38:3 Oxf. J. Leg. Stud., 451; Seibert-Fohr, Prosecuting Serious Human Rights Violations (2009), $111 \mathrm{ff} . ;$ ChevalierWatts, 'Effective Investigations under Article 2 of the European Convention on Human Rights: Securing the Right to Life or an Onerous Burden on a State?' (2010) 21 EJIL, 701; Mavronicola, 'Taking Life and Liberty Seriously' (2017) 80(6) MLR, 1026; Roberti di Sarsina, Transitional Justice and a State's Response to Mass Atrocity (2019), $71 \mathrm{ff}$.

4 The debate on amnesties and the ECtHR is still ongoing. See e.g. Mallinder, 'Investigations, Prosecutions and Amnesties under Articles $2 \& 3$ of the European Convention on Human Rights' (2015) Transitional Justice Institute, Research Paper no. 15-05, available at: https://papers.ssrn.com/sol3/papers.cfm?abstract_id=266810 6 (last accessed 23 September 2020); Schabas, The European Convention on Human Rights: A Commentary (2015), 128; Jackson, 'Amnesties in Strasbourg' (2018) 38:3, 451; see Roberti di Sarsina, Transitional Justice and a State's Response to Mass Atrocity (2019), $140 \mathrm{ff}$.

5 ECtHR, Judgment, 11 February 2020, Vovk and Bogdanov v Russia, Application No. 15613/10, Joint Concurring Opinion of Judges Pinto de Albuquerque and Elósegui. 


\section{B. Protecting Human Rights through Criminal Law: The Jurisprudence of the ECtHR}

Treaties and conventions designed to prevent international crimes, such as genocide, torture, apartheid and enforced disappearances, contain clear obligations to investigate and prosecute the commission of the crimes enshrined therein. ${ }^{6}$ Comprehensive human rights treaties, such as the International Covenant on Civil and Political Rights, the American Convention on Human Rights and the ECHR, confer substantive rights vis-àvis the State upon individuals. Little can be inferred from these treaties regarding the means by which those rights are to be protected. It is thus the practice of international courts and bodies that has clarified the means by which such rights are to be enforced, mainly in the jurisprudence stemming from Article 2 ('right to life') and Article 3 ('prohibition of torture') of the ECHR.

The obligations to criminalise, investigate, and prosecute that arise from Article 2 and Article 3 of the ECHR are often read together with Article 1 ('obligation to respect and protect human rights'), and often discussed in context of Article 13 ('right to an effective remedy'). ${ }^{7}$ Article 2 and Article 3 of the Convention enshrine 'one of the basic values of the democratic so-

6 The Convention on the Prevention and Punishment of the Crime of Genocide (Articles 1, 4, 6), the Convention against Torture and Other Cruel, Inhumane or Degrading Treatment or Punishment (Articles 6 para. 2, 7, 12, 16), the International Convention on the Suppression and Punishment of the Crime of Apartheid (Article 4), and the International Convention for the Protection of All Persons from Enforced Disappearance (Articles 3, 10, para. 2, 12).

7 Article 8 ('right to respect for private and family life') is also highly relevant in this context. In $X$ and $Y v$ The Netherlands, the Court found that the State's failure to enact criminal law provisions breached its positive obligations to secure enjoyment of the right to private life as guaranteed under Article 8 ECHR (ECtHR, Judgment, 26 March 1985, $X$ and $Y v$ The Netherlands, Application No. 8978/80). While admitting that State parties do have a margin of appreciation in determining the means to secure the rights protected by the Convention (para. 24), the Court found that, given the case's specific circumstances of the rape of a handicapped minor, only criminal law measures were appropriate (para. 27). The Court rejected the view that civil damages could suffice on the grounds that they would not achieve effective deterrence. In M.C. $v$ Bulgaria, the Court found that Article 8 and Article 3 of the Convention require 'the penalisation and effective prosecution of any nonconsensual sexual act, including in the absence of physical resistance by the victim' (ECtHR, Judgment, 4 December 2003 M.C. v Bulgaria, Application No. 39272/98, para. 166). Other cases in which the Court found a violation of Article 8 or Article 8 and Article 3 based on the failure to enact effective criminal law provisions or prosecute individuals also concerned sexual abuse of minors and rape. See ECtHR, 
cieties making up the Council of Europe. ${ }^{8}$ Their fundamental importance is reflected in their prominent position in the Convention and explains the expanding criminal law protection offered by the Court.

\section{Positive Obligations and Criminal Law}

Besides the negative obligation not to interfere with the right to life, a State is under a positive obligation to protect the right to life. The positive obligation consists of two aspects: (1) providing a 'regulatory framework', and (2) taking operational measures aimed at preventing human rights infringements. ${ }^{9}$ As the Court most recently stated in Makaratzis v. Greece, a State must

take appropriate steps within its internal legal order to safeguard the lives of those within its jurisdiction [...]. This involves a primary duty on the State to secure the right to life by putting in place an appropriate legal and administrative framework to deter the commission of offences against the person, backed up by law-enforcement machinery for the prevention, suppression and punishment of breaches of such provisions. $^{10}$

The Court made clear that an effective legal system, as required under Article 2 ECHR, 'may, and under certain circumstances must, include recourse to the criminal law.' ${ }^{11}$ In other cases, the Court stated that the State

Judgment (GC), 12 November 2013, Söderman v. Sveden, Application No. 5786/08; ECtHR, Judgment, 28 May 2020, Z. v. Bulgaria, Application No. 39257/17. ECtHR, Judgment, 28 May 2020, Z. v. Bulgaria, Application No. $39257 / 17$ (request for referral to the Grand Chamber pending).

8 ECtHR, Judgment, 10 September 2020, Shuriyya Zeynalov v. Azerbaijan, Application No. 69460/12, para. 66; see also ECtHR, Judgment, 1 September 2020, R.R. and R.D. v Slovakia, Application No. 20649/8, para. 146.

9 ECtHR, 'Guide on Article 2 of the European Convention on Human Rights, Right to Life', updated 31 August 2020, https://www.echr.coe.int/Documents/Gui de_Art_2_ENG.pdf, 8.

10 ECtHR, Judgment (GC), 20 December 2004, Makaratzis v Greece, No. 50385/99 para. 57; see also ECtHR, Judgment, 4 August 2020, Tërshana v Albania, Application No. 48756/14, para. 147.

11 ECtHR, Decision, 11 March 2014, Cioban v Romania, Application No. 18295/08, para. 25; see also ECtHR, Judgment, 5 January 2010, Railean v Moldova, Application No. 23401/04, para. 27; ECtHR, Judgment, 6 February 2020, Sakvarelidze v Georgia, Application No. 40394/10, para. 51. 
must put in place 'effective criminal-law provisions. ${ }^{12}$ Furthermore, the State is under a duty to ensure 'the effective functioning' of the framework designed to protect the right to life. ${ }^{13}$ In light of this, the obligation to put in place and to enforce criminal law norms prohibiting the taking of life can be described as the centre of the positive obligations of the State to secure the protection of the right to life and the freedom from torture. ${ }^{14}$

Positive obligations apply 'in the context of any activity, whether public or not, in which the right to life may be at stake. ${ }^{15}$ Thus, they apply in a variety of different contexts including a broad range of dangerous activities ${ }^{16}$ but also in the sphere of public health ${ }^{17}$ and road safety. ${ }^{18}$ They also apply in the context of armed conflicts. ${ }^{19}$

In Osman v. The United Kingdom, the Court held that the positive obligations apply not only to violations of the right to life through agents of the State, but also to acts of non-State agents. In that regard, the Court stated that

[i]t is thus accepted by those appearing before the Court that Article 2 of the Convention may also imply in certain well-defined circumstances a positive obligation on the authorities to take preventive oper-

12 ECtHR, Judgment, 2 June 2020, A. and B. v Romania, Application Nos. 48442/16 and 48831/16, para. 116; ECtHR, Judgment, 4 December 2012, R.R. and Others $v$ Hungary, Application No. 19400/11, para 28; ECtHR, Judgment, 12 May 2020, Danciu and Others $v$ Romania, Application No. 48395/16, para. 76.

13 ECtHR, Judgment, 17 September 2020, Kotilainen and others $v$ Finland, Application No. 62439/12, para. 66; see also ECtHR, 2 February 2016, Cavit Tinarlioğluv Turkey, Application No. 3648/04, para. 86.

14 See Schabas, The European Convention on Human Rights: A Commentary (2015), 127.

15 ECtHR, Judgment (GC), 14 July 2014, Centre for Legal Resources on behalf of Valentin Câmpeanu v Romania, Application No. 47848/08, para. 130.

16 ECtHR, Judgment (GC), 30 November 2004, Öneryildiz v Turkey, Application No. 48939/99, para. 101; ECtHR, Judgment,.17 November 2015, M. Ozel and Others $v$ Turkey, Application Nos. 14350/05, 15245/05, 6051/05, paras. 198, 190.

17 ECtHR, Judgment (GC), 17 January 2002, Calvelli and Ciglio v Italy, Application No. 32967/96, para. 49.

18 ECtHR, Judgment, 24 May 2011, Anna Todorova $v$ Bulgaria, Application No. 23302/03, para. 72 .

19 Gioia, 'The Role of the European Court of Human Rights in Monitoring Compliance with Humanitarian Law in Armed Conflict' in Ben-Naftali (ed), International Humanitarian Law and International Human Rights Law (2011), 201 (234 ff.). 
ational measures to protect an individual whose life is at risk from the criminal acts of another individual. ${ }^{20}$

However, the Court was careful to limit this obligation when it acknowledged that,

bearing in mind the difficulties involved in policing modern societies, the unpredictability of human conduct and the operational choices which must be made in terms of priorities and resources, such an obligation must be interpreted in a way which does not impose an impossible or disproportionate burden on the authorities. Accordingly, not every risk to life can entail for the authorities a Convention requirement to take operational measures to prevent that risk from materialising. ${ }^{21}$

In general, the conditions for finding a violation of the positive obligations are quite stringent. In this sense, the Court clarified that:

it must be established that the authorities knew or ought to have known at the time, of the existence of a real and immediate risk to the life of an identified individual or individuals from the criminal acts of a third party and that they failed to take measures within the scope of their powers which, judged reasonably, might have been expected to avoid that risk. ${ }^{22}$

However, in a few cases, the Court also found the positive obligations to be violated when there was a risk not to identified individuals but to members of the public more generally. These arose from criminal acts

20 ECtHR, Judgment (GC), 28 October 1998, Osman v The United Kingdom, Application No. 87/1997/871/1083, para. 115; see also ECtHR, Judgment, 4 August 2020, Tërshana v Albania, Application No. 48756/14, para. 147; ECtHR, Judgment (GC), 31 January 2019, Fernandes de Oliveira v Portugal, Application No. 78103/14, para. 108.

21 ECtHR, Judgment (GC), 28 October 1998, Osman $v$ The United Kingdom, Application No. 87/1997/871/1083, para. 116; see also ECtHR, Judgment, 4 August 2020, Tërshana v Albania, Application No. 48756/14, para. 147; ECtHR, Judgment (GC), 31 January 2019, Fernandes de Oliveira v Portugal, Application No. 78103/14, para. 108.

22 ECtHR, Judgment, 17 September 2020, Kotilainen and others $v$ Finland, Application No. 62439/12, para. 69; see also ECtHR, Judgment (GC), 28 October 1998, Osman $v$ The United Kingdom, Application No. 87/1997/871/1083, para. $105 \mathrm{f}$. 
of individuals under the control of State authorities, for example, the criminal acts of dangerous prisoners. ${ }^{23}$

With regard to Article $3 \mathrm{ECHR}$, positive obligations have played a less prominent role. William Schabas notes that the ECtHR has applied Article 3 ECHR mainly where the risk to the individual emanates from intentional acts by State authorities. ${ }^{24}$ This puts the negative obligation to refrain from such acts in the foreground. In that regard, the State is required to 'take measures designed to ensure that individuals within their jurisdiction are not subjected to ill-treatment, including ill-treatment administered by private individuals. ${ }^{25}$

\section{The Procedural Obligations to Investigate and Prosecute}

Articles 2 and 3 read in conjunction with Article 1 of the Convention are interpreted to enshrine the procedural obligations to investigate and prosecute. ${ }^{26}$ Initially, in the landmark case McCann and Others $v$. The United Kingdom, the Court derived procedural obligations in the context of the use of lethal force by State agents. The Court grounded these obligations in the finding that a prohibition of arbitrary killings would be ineffective if the lawfulness of killings through State agents were not subject to review. ${ }^{27}$ Since then, the Court has expanded the procedural obligations to a number of other situations, including when the loss of life is not the result of the use of force. ${ }^{28}$

23 ECtHR, Judgment (GC), 24 October 2002, Mastromatteo v Italy, Application No. 37703/97, para. 69.

24 Schabas, The European Convention on Human Rights: A Commentary (2015), 191.

25 ECtHR, Judgment, 26 May 2020, I.E. $v$ The Republic of Moldova, Application No. 45422/3, para. 38 .

26 In Nikolova and Velichkova $v$ Bulgaria, the Court even took issue with the length of a criminal sentence, see ECtHR, Judgment, 20 December 2007, Nikolova and Velichkova v Bulgaria, Application No. 7888/03, para. $60 \mathrm{ff}$.

27 ECtHR, Judgment (GC), 27 September 1995, McCann and Others $v$ The United Kingdom, Application No. 18984/9, para. 61. See also ECtHR, Guide on Article 2 of the European Convention on Human Rights, Right to Life, Updated 31 August 2020, 31 .

28 Chevalier-Watts illustrates how the obligation to conduct an investigation expanded since McCann and others $v$ The United Kingdom. Chevalier-Watts. 'Effective investigations under Article 2 of the European Convention on Human Rights: Securing the Right to Life or an Onerous Burden on a State?' (2010) 21 EJIL 701 (705 ff.). 
It is well established in the jurisprudence of the Court that the substantive Articles 2 and 3 of the Convention include procedural requirements. ${ }^{29}$ From 1959 to 2019, the Court found a violation of Article 2 and Article 3 for lack of effective investigation in 816 (Article 2) and 893 (Article 3) cases, respectively. ${ }^{30}$ As anticipated, this procedural dimension arises from the respective article read in conjunction with Article 1 of the Convention, according to which State Parties have a duty to 'secure to everyone within their jurisdiction the rights and freedoms defined in [...] [the] Convention. ${ }^{31}$ In recent cases, the Court often simply refers to the 'procedural obligation' or 'procedural limb' of Article 2 and Article 3 of the Convention, rather than explicitly deriving the obligation from the respective article read in conjunction with Article 1 of the Convention. ${ }^{32}$ In Šilih v. Slovenia, elaborating on its prior jurisprudence, the Court concluded that 'the procedural obligation to carry out an effective investigation under Article 2 has evolved into a separate and autonomous duty. ${ }^{33}$

The obligations to investigate and prosecute arising from Articles 2 and 3 should not be confused with the obligations arising from Article 13 of the Convention. Generally, State Parties enjoy a margin of appreciation regarding the adoption of effective remedies. ${ }^{34}$ However, the Court significantly narrows down this margin of appreciation when the taking of life

29 See e.g. ECtHR, Judgment (GC), April 2009, Šilih v Slovenia, Application No. 71463/019, para 153; ECtHR, Judgment (GC), 27 September 1995, McCann and Others $v$ The United Kingdom, Application No. 18984/9, paras. 157-164. See also Schabas, The European Convention on Human Rights: A Commentary (2015), $134 \mathrm{ff}$. (on Article 2), $191 \mathrm{ff}$. (on Article 3).

30 Overview ECHR 1959 - 2019, European Court of Human Rights 2020, https://w ww.echr.coe.int/Documents/Overview 19592019_ENG.pdf.

31 See e.g. ECtHR, Judgment (GC), 6 April 2000, Labita v Italy, Application No. 26772/95, para. 131; ECtHR, Judgment 22 October 2009, Isayev v Russia, Application No. 20756/04, para. 103.

32 ECtHR, Judgment, 4 August 2020, Tërshana v Albania, Application No. 48756/14, para. 153; ECtHR, Judgment, 9 July 2019, Volodina v Russia, Application No. 41261/17, para. 92 (on Article 3). But see ECtHR, Judgment, 12 November 2019, A. $v$ Russia, Application No. 37735/09, para. 53; ECtHR, Judgment, 30 January 2020, Saribekyan and Balyan v Azerbaijan, Application No. 35746/11, para. 62; but see ECtHR, Judgment, 1 September 2020, R.R. and R.D. $v$ Slovakia, Application No. 20649/18, para. 176 (where the Court derives the procedural obligation to conduct an effective investigation from Articles 2 and 3 in conjunction with Article 1).

33 ECtHR, Judgment (GC), 9 April 2009, Šilih $v$ Slovenia, Application No. 71463/019, para. 159.

34 Seibert-Fohr, Prosecuting Serious Human Rights Violations (2009), 124; ECtHR, Judgment, 14 December 2000, Gül v Turkey, Application No. 22676/93, para. 100. 
is concerned. ${ }^{35}$ An effective remedy, according to the Court entails 'in addition to the payment of compensation where appropriate, a thorough and effective investigation capable of leading to the identification and punishment of those responsible. ${ }^{36}$

The difference between the procedural obligations derived from substantive Articles 2 and 3 in conjunction with Article 1, and obligations derived from Article 13 of the Convention is however not entirely clear in the jurisprudence of the Court. ${ }^{37}$ In that regard, Anja Seibert-Fohr observes that the Court uses the same terminology in the context of Article 13 ECHR as in the context of the substantive articles. ${ }^{38}$ The difference seems to be related to the fact that Article 13 ECHR, as opposed to the substantive articles, confers an individual right upon the victim. ${ }^{39}$ Schabas argues that the Court has considered the duties stemming from Article 13 to be broader than the procedural obligations stemming from either the substantive Article 2 or 3 of the Convention. ${ }^{40}$

\section{The Standard for an Effective Investigation}

In Isayeva v. Russia, the Court clarified the standards of the procedural obligations required for the protection of the right to life. From Article 2

35 Seibert-Fohr, Prosecuting Serious Human Rights Violations (2009), 124; ECtHR, Judgment, 14 December 2000, Gül v Turkey, Application No. 22676/93, para. 100; ECtHR, Judgment, 3 April 2000, Keenan $v$ The United Kingdom, Application No. 27229/95, para. 123.

36 ECtHR, Judgment, 24 July 2014, Husayn (Abu Zubaydah) v Poland, Application No. 7511/13, para. 541; ECtHR, Judgment, 13 June 2002, Anguelova v Bulgaria, Application No. 38361/97, para. $161 \mathrm{f}$; ECtHR, Judgment (GC), 13 December 2012, El Masri $v$ The former Yugoslav Republic of Macedonia, Application No. 39630/09, para. 255.

37 See Seibert-Fohr, Prosecuting Serious Human Rights Violations (2009), $124 \mathrm{f.}$

38 Id., 125.

39 Ibid.

40 Schabas, The European Convention on Human Rights: A Commentary (2015), 552; citing ECtHR, 24 July 2014, Husayn (Abu Zubaydah) v Poland, Application No. 7511/13, para. 542; ECtHR, Judgment (GC), 13 December 2012, El Masri v The former Yugoslav Republic of Macedonia, Application No. 39630/09, para. 255; ECtHR, Judgment, 24 February 2005, Khashiyev and Akayeva $v$ Russia, Application Nos. 57942/00 and 57945/00, para. 183; ECtHR, Judgment, 25 May 1998, Kurt v Turkey, Application No. 15/1997/799/1002, para. 140; ECtHR, Judgment, 18 June 2002, Orhan v Turkey, Application No. 25656/94, para. 384; ECtHR, Judgment, 28 March 2002, Kiliçv Turkey, Application No 22492/93, para. 93. 
in conjunction with Article $1 \mathrm{ECHR}$, the Court inferred that 'there should be some form of effective official investigation when individuals have been killed as a result of the use of force.' ${ }^{41}$ The Court then clarified what the relevant criteria are. Most notably the investigation must be independent, ex officio, prompt, subject to public scrutiny and 'capable of leading to a determination of whether the force $[\ldots]$ was or was not justified in the circumstances $[\ldots]$ and to the identification and punishment of those responsible. ${ }^{42}$ With regard to the investigation being capable of leading to conclusions about justification of the use of force as well as the identification and punishment of those responsible, the Court was careful to state that this is 'not an obligation of result, but of means. ${ }^{43}$ However, the Court left open the question of the legal nature of the investigation. While stressing that " $[t]$ he essential purpose of such investigation is to secure the effective implementation of the domestic laws which protect the right to life and, in those cases involving State agents or bodies, to ensure their accountability for deaths occurring under their responsibility', the Court stated that '[w]hat form of investigation will achieve those purposes may vary in different circumstances. ${ }^{34}$ This understanding was confirmed in more recent decisions too. ${ }^{45}$

However, the duty to conduct an investigation arises 'in all cases of killing and other suspicious deaths, whether the perpetrators were private persons or State agents or are unknown. ${ }^{46}$ The obligation to investigate also applies to cases arising from an alleged infringement of the right to life that did not result in the death of the person but in life-threatening injuries. ${ }^{47}$ In Razvozzhayev v. Russia \& Ukraine and Udaltsov v. Russia, the Court made clear that the requirements regarding the official investigation are similar whether treatment contrary to the Convention (in this case

41 ECtHR, Judgment, 24 February 2005, Isayeva v Russia, Application No. 57950/00, para. 209.

42 Id., para. $210-214$.

43 Id., para. 212.

44 Id., para. 210.

45 ECtHR, Judgment, 28 January 2020, Nicolaou v Cyprus, Application No. 29068/10, paras. 132 ff.; ECtHR, Judgment, 3 October 2019, Fountas $v$ Greece, Application No. 50283/13, para. $67 \mathrm{ff}$.

46 ECtHR, Judgment, 26 May 2020, Makuchyan and Minasyan v Azerbaijan and Hungary, Application No. 17247/13, para. 154; see also ECtHR, Judgment, 26 July 2007, Angelova and Iliev v Bulgaria, Application Nos. 55523/00, para. 93.

47 See e.g. ECtHR, Judgment, 12 May 2020, Danciu and others $v$ Romania, Application No. $48395 / 16$, para. 80. 
Article 3 ECHR) was inflicted by private individuals or through State agents. ${ }^{48}$

In Labita v. Italy, the Court confirmed that the procedural requirements arising from Article 3 ECHR in conjunction with Article 1 of the Convention are similar to those under Article 2 ECHR. In this sense, the Court stated that:

where an individual makes a credible assertion that he has suffered treatment infringing Article 3 at the hands of the police or other similar agents of the State, that provision, read in conjunction with the State's general duty under Article 1 of the Convention [...] requires by implication that there should be an effective official investigation. As with an investigation under Article 2, such investigation should be capable of leading to the identification and punishment of those responsible [...]. Otherwise, the general legal prohibition of torture and inhuman and degrading treatment and punishment would, despite its fundamental importance $[. .$.$] , be ineffective in practice and it would$ be possible in some cases for agents of the State to abuse the rights of those within their control with virtual impunity. ${ }^{49}$

Consequently, the same standards as regarding the procedural limb of Article 2 ECHR apply.

In this context, it should also be noted that the failure to comply with the procedural obligation to conduct an effective investigation into the fate of missing persons may constitute inhumane treatment of such persons' relatives, and thus a violation of Article 3 of the Convention. ${ }^{50}$ In El Masri v. The former Yugoslav Republic of Macedonia, the Court found that the lack of an adequate investigation impacted the "right to the truth. ${ }^{51}$ In this case, the procedural obligation to investigate arose from a violation of Article 3 ECHR. The Court made clear that the investigation was fundamental 'not only for the applicant and his family, but also for other victims of

48 ECtHR, Judgment, 19 November 2019, Razvozzhayev $v$ Russia \& Ukraine and Udaltsov v Russia, Application Nos. 75734/12, 2695/15, 55325/15, para. 171.

49 ECtHR, Judgment (GC), 6 April 2000, Labita v Italy, Application No. 26772/95, para. 131.

50 ECtHR, Judgment (GC), 10 May 2001, Cyprus $v$ Turkey, Application No. 25781/94, paras. $157 \mathrm{f}$.

51 ECtHR, Judgment (GC), 13 December 2012, El Masriv The former Yugoslav Republic of Macedonia, Application No. 39630/09, para. 191. 
similar crimes and the general public, who had the right to know what had happened. 52

Finally, in a case concerning Article 2 ECHR, the Court emphasised the need for a vigorous and impartial investigation where an act is racially motivated, 'having regard to the need to reassert continuously society's condemnation of racism and to maintain the confidence of minorities in the ability of the authorities to protect them from the threat of racist violence. ${ }^{53}$ More recently, both in cases concerning Articles 2 and 3 of the Convention, the Court stated that domestic- and gender-based violence call for an investigation to be pursued with vigour. ${ }^{54}$

\section{Criticism of the Court's Approach to Criminal Law Measures}

Against this backdrop, some authors have argued that positive obligations as interpreted in the jurisprudence of the Court generally, and the ECtHR's approach to criminal law measures specifically, indicate a potential 'coercive overreach. ${ }^{55}$ The potential for 'coercive overreach', Natasa Mavronicola argues, arises from the ECtHR leaning towards conflating State responsibility for the breach of the negative obligations under Article 2 ECHR with individual criminal liability. ${ }^{56}$ According to this author, the Court's 'tendency to seek punitive redress and its occasional apparent endorsement of arguments equating Article 2 breaches with criminal

52 Ibid.

53 See ECtHR, Judgment (GC), 6 May 2003, Menson $v$ The United Kingdom, Application No. 47916/99, para. 1.

54 ECtHR, Judgment, 4 August 2020, Tërshana v Albania, Application No. 48756/14, para. 160; ECtHR, Judgment, 9 July 2019, Volodina v Russia, Application No. 41261/17, para. 92 (on Article 3).

55 Mavronicola, 'Taking Life and Liberty Seriously' (2017) 80(6) MLR, 1026 (building on the more general account of Lazarus, 'Positive Obligations and Criminal Justice: Duties to Protect or Coerce?' in Zedner and Roberts (eds) Principles and Values in Criminal Law and Criminal Justice: Essays in Honour of Andrew Ashworth (2012), 135 (149)). For arguments on procedural obligations as burdens on the State, see Chevalier-Watts, 'Effective investigations under Article 2 of the European Convention on Human Rights: Securing the Right to Life or an Onerous Burden on a State?' (2010) 21 EJIL 701, 709 ff. (concluding that procedural obligations are not too burdensome on the State).

56 Mavronicola, 'Taking Life and Liberty Seriously' (2017) 80(6) MLR, 1026 (1037 ff.). 
offences via positive obligations is bordering on supranational criminal law-making.' ${ }^{57}$

These are legitimate concerns arising from the Court's involvement with criminal law. For example, in Nikolova and Velichkova v. Bulgaria, the Court took issue with the length of a criminal sentence. ${ }^{58}$ This seems to conflict with the 'obligation of means, not result' doctrine of the Court and could therefore be conceived as 'coercive overreach'.59 This case, however, remains the exception. As a matter of fact, the Court has been careful not to refer to an obligation to punish. ${ }^{60}$ In finding a need to put in place criminal law provisions, investigate human rights violations and prosecute alleged perpetrators, the Court has maintained a nuanced approach in order not to interfere with procedural safeguards, justifications and excuses under domestic criminal law. In this sense, the ECtHR made clear that the Convention does not confer upon anyone the individual right to have someone prosecuted, not to mention to have someone punished. ${ }^{61}$ In Öneryildiz v. Turkey, for example, the Court stated that Article 2 ECHR does not entail a right 'to have third parties prosecuted or sentenced for a criminal offence $[\ldots]$ or an absolute obligation for all prosecutions to result in conviction, or indeed in a particular sentence [...]'.62 Similarly, in Perez v. France, the Court stated 'that the Convention does not confer any right $[\ldots]$ to "private revenge" or an actio popularis. ${ }^{63}$

More importantly, in Mosendz v. Ukraine, the Court elaborated on the distinction between domestic criminal law and international law:

It should be specified that criminal-law liability under national legislation is distinct from a State's international-law responsibility under the Convention. In determining whether there has been a breach of Arti-

57 Id., 1040.

58 ECtHR, Judgment, 20 December 2007, Nikolova and Velichkova v Bulgaria, Application No. 7888/03, para. $60 \mathrm{ff}$.

59 The term 'coercive overreach' in this context stems from Lazarus, 'Positive Obligations and Criminal Justice: Duties to Protect or Coerce?' in Zedner and Roberts (eds) Principles and Values in Criminal Law and Criminal Justice: Essays in Honour of Andrew Ashworth (2012), 135, and was applied to the ECtHR by Mavronicola, 'Taking Life and Liberty Seriously' (2017) 80(6) MLR, 1026.

60 Seibert-Fohr, Prosecuting Serious Human Rights Violations (2009), 115; Roberti di Sarsina, Transitional Justice and a State's Response to Mass Atrocity (2019), 77.

61 ECtHR, Judgment (GC), 30 November 2004, Öneryildiz v Turkey, Application No. 48939/99, para. 96 .

62 Ibid.

63 ECtHR, Judgment (GC), 12 February 2004, Perez $v$ France, Application No. 47287/99, para. 70 . 
cle 2, the Court does not assess the criminal responsibility of those directly or indirectly concerned. Its competence is confined to the State's international responsibility under the Convention, the provisions of which are to be interpreted and applied on the basis of the object and purpose of the Convention and in the light of the relevant principles of international law. In other words, the responsibility of a State under the Convention, arising for the acts of its organs, agents and servants, is not to be confused with the domestic legal issues of individual criminal responsibility under examination in the national criminal courts. The Court is not concerned with reaching any findings as to guilt or innocence in that sense. ${ }^{64}$

In light of this, the claim that the jurisprudence of the Court resembles criminal law making cannot be sustained. Nevertheless, it appears that the Court's jurisprudence is lacking in clarity, especially when it comes to the obligation of States Parties in response to unintentional breaches of the right to life. In this specific area, the absence of a systematic approach has recently surfaced in the abovementioned joint concurring opinion of Judges Paulo Pinto de Albuquerque and María Elósegui in Vovk and Bogdanov v. Russia. ${ }^{65}$

\section{Unintentional Infliction of Death or Life-Threatening Injuries}

Perhaps the least established aspect of the Court's jurisprudence on criminal law measures relates to unintentionally inflicted harm. This category covers a wide spectrum, from the loss of life due to medical negligence by private actors to gross negligence on account of State authorities. In these cases, there is a level of uncertainty as to whether criminal investigation and prosecution is required.

In Banel v. Lithuania, the Court held that a State might be held responsible for a violation of Article 2 ECHR as a result of the domestic legal system's inability to secure accountability for negligent acts endangering

64 ECtHR, Judgment, 17 January 2013, Mosendz v Ukraine, Application No. 52013/08, para. 95 .

65 ECtHR, Judgment, 11 February 2020, Vovk and Bogdanov v Russia, Application No. 15613/10, Joint Concurring Opinion of Judges Pinto de Albuquerque and Elósegui. 
or resulting in a loss of human life. ${ }^{66}$ It is undisputed that the positive obligations require States Parties to have in place a judicial system that is capable of establishing the facts including the cause of death and holding accountable those who are responsible and providing appropriate redress to the victim. ${ }^{67}$ However, it is not always clear whether criminal proceedings are required to fulfil these requirements. As a rule, in cases arising from non-intentional death or life-threatening injuries, Article 2 ECHR does not necessarily require criminal law remedies. ${ }^{68}$ However, under 'exceptional circumstances', civil remedies might be insufficient. The Court found that to be the case 'when lives have been lost as a result of events occurring under the responsibility of the public authorities and where the negligence attributable to those authorities went beyond an error of judgment or carelessness. ${ }^{69}$ In Oneryildiz v. Turkey, the Court stated that in such cases of gross negligence on the side of public authorities, the same principles apply as in cases arising from the use of lethal force. ${ }^{70}$ In these cases, 'the fact that those responsible for endangering life have not been charged with a criminal offence or prosecuted may amount to a violation of Article 2. ${ }^{71}$ The Court considered such circumstances to apply to a large number of cases concerning, inter alia, the public health sector, ${ }^{72}$ military activities $^{73}$ and waste collection sites. ${ }^{74}$ In Sinim v. Turkey, the Court con-

66 ECtHR, Judgment, 18 June 2013, Banel v Lithuania, Application No. 14326/11, para. 70.

67 ECtHR, Guide on Article 2 of the European Convention on Human Rights, Right to Life, updated 31 August 2020, 41.

68 ECtHR, Judgment, 6 June 2017, Sinim v Turkey, Application No. 9441/10, para. 62; see also ECtHR, Judgment (GC), 17 January 2002, Calvelli and Ciglio v Italy, Application No. 32967/96, para. 51.

69 See e.g. ECtHR, Judgment, 27 January 2015, Asiye Genç v Turkey, Application No. 24109/07, para. 73; ECtHR, Judgment, 6 June 2017, Sinim v Turkey, Application No. 9441/10, para. 62; ECtHR, Judgment, 11 February 2020, Vovk and Bogdanov $v$ Russia, Application No. 15613/10, para. 64; ECtHR, Judgment (GC), 30 November 2004, Oneryildiz v Turkey, Application No. 48939/99, para. 93.

70 ECtHR, Judgment (GC), 30 November 2004, Öneryildiz v Turkey, Application No. 48939/99, para. 93.

71 Ibid.

72 ECtHR, Judgment, 9 April 2019, Mehmet Şentürk and Bekir Şentürk v Turkey, Application No. 13423/09, para. 104; ECtHR, Judgment, 27 January 2015, Asyie Gençv Turkey, Application No. 24109/07, para. 73.

73 ECtHR, Judgment, 4 February, Oruk v Turkey 2014, Application No. 33647/04, paras. 56 ff.; ECtHR, Judgment, 11 February 2020, Vovk and Bogdanov v Russia, Application No. 15613/10, para. 74.

74 ECtHR, Judgment (GC), 30 November 2004, Öneryildiz v Turkey, Application No. 48939/99, para. 71 . 
sidered a criminal investigation necessary although public authorities were not involved in the dangerous activity. ${ }^{75}$ However, the Court continues to consider these cases the exception to the norm whereby civil remedies are sufficient in the case of unintentional infliction of death. ${ }^{76}$ In Nicolae Virgiliu Tănase v. Romania, the Court held that once it has been established that death or a life-threatening injury has not been inflicted intentionally, civil remedies are to be considered sufficient, 'regardless of whether the person presumed responsible for the incident is a private party or a State agent. ${ }^{77}$

The Judges Paulo Pinto de Albuquerque and María Elósegui strongly criticised the approach taken in Nicolae Virgiliu Tănase v. Romania, and the Court's comparatively lenient approach to negligence situations as being 'both incompatible with international law and contrary to Council of Europe member State practice'. ${ }^{78}$ Pointing to General Comment No. 36 of the United Nations Human Rights Committee on the right to life, ${ }^{79}$ the judges argued that there is a trend in international law towards remedying unintentional threats to life. ${ }^{80}$ In addition, they pointed to the practice of the Member States of the Council of Europe, which generally provide for criminal law remedies in cases of death or injuries due to medical negligence. The judges went even further in their criticism:

[i]n spite of remaining linguistically attached to the statement of principle in Calvelli and Ciglio v. Italy, according to which the Convention did not necessarily require the provision of a criminal-law remedy when the right to life had been infringed unintentionally, the Court has on several occasions made it clear that criminal remedies would be necessary, such as when human-caused harm resulted from operation of waste-collection sites and military activities [...]. As a matter of

75 ECtHR, Judgment, 6 June 2017, Sinim v Turkey, Application No. 9441/10, para. 62.

76 ECtHR, Judgment, 28 January 2010, Zinatullin $v$ Russia, Application No. 10551/10, para. 35 .

77 ECtHR, Judgment (GC), 25 June 2019, Nicolae Virgiliu Tănase v Romania, Application No. 41720/13, para. 163.

78 ECtHR, Judgment, 11 February 2020, Vovk and Bogdanov v Russia, Application No. 15613/10, Joint Concurring Opinion of Judges Pinto de Albuquerque and Elósegui.

79 Human Rights Committee, 30 October 3018, CCPR/C/GC/36, paras. 20, 27, 28.

80 ECtHR, Judgment, 11 February 2020, Vovk and Bogdanov v Russia, Application No. 15613/10, Joint Concurring Opinion of Judges Pinto de Albuquerque and Elósegui. 
fact, it seems that the exception has become the rule, since the Court has found more often than not that the lack of criminal remedies constituted a violation of Article $2 .{ }^{81}$

In light of the forceful arguments made in this concurring opinion, it remains to be seen how the Court's jurisprudence in negligence cases will develop. Currently, there is a certain degree of uncertainty ${ }^{82}$ due to the fact that it is not entirely clear under what circumstances civil law remedies suffice. In Nicolae Virgiliu Tănase v. Romania, the Court stated that civil remedies suffice once it has been established that death was inflicted unintentionally. However, when it is not clear whether death or injuries are inflicted intentionally or unintentionally, the Court might have to draw the line between negligence and intentional conduct, and thus engage with a question at the heart of criminal law. This could be perceived as yet another interference in domestic matters of criminal law.

\section{The Rationales behind the Obligations to Criminalise, Investigate, and Prosecute}

In order to better understand the rationale behind the obligations to criminalise, investigate, and prosecute, the concept of 'procedural protection' should be employed..$^{83}$ As explained earlier, procedural obligations stem from the substantive right in question combined with the obligation to secure to everyone the rights and freedoms under Article 1 ECHR. They are considered to be 'separate and autonomous' from the substantive obligations, and thus independent from a finding of a substantive breach. ${ }^{84} \mathrm{~A}$ finding that the substantive right has not been violated does not preclude

81 Ibid.

82 Mavronicola also raises this issue, although not in relation to the Nicolae Virgiliu Tănase case: Mavronicola, 'Taking Life and Liberty Seriously' (2017) 80(6) MLR, 1026 (1045).

83 See Seibert-Fohr, Prosecuting Serious Human Rights Violations (2009), 118; see also Schabas, The European Convention on Human Rights: A Commentary (2015), 191; Roberti di Sarsina, Transitional Justice and a State's Response to Mass Atrocity (2019), 78.

84 ECtHR, Judgment (GC), 9 April 2009, Šilih v Slovenia, Application No. 71463/01, para 159; Schabas, The European Convention on Human Rights: A Commentary (2015), 134; Roberti di Sarsina, Transitional Justice and a State's Response to Mass Atrocity (2019), 78; See also ECtHR,' Guide on Article 2 of the European Convention on Human Rights, Right to Life', updated 31 August 2020, https://www.echr. coe.int/Documents/Guide_Art_2_ENG.pdf, 33. 
an applicant from lodging a complaint under Article 13 ECHR, and the Court may still find a violation of the procedural obligations. ${ }^{85}$

Seibert-Fohr convincingly argues that in search of the rationale behind criminal law measures in the Court's jurisprudence, one should distinguish between different aspects of criminal law. Criminalisation and enforcement of criminal law are usually regarded as 'matters of general human rights protection' by the Court, whereas protection of an individual victim leads to a focus on the investigation. ${ }^{86}$ Whereas there is no right to have a third party prosecuted or punished, the Court found that the victim is entitled to an investigation. ${ }^{87}$ However, the Court itself does not distinguish clearly between these aspects.

In X. and Y. v. The Netherlands, the Court clearly explains why positive obligations sometimes require recourse to criminal law. ${ }^{88}$ In this case, the Court made clear that 'effective deterrence is indispensable' when fundamental values, and in this case 'essential aspects of private life', are at stake. Deterrence 'can be achieved only by criminal law provisions; indeed, it is by such provisions that the matter is normally regulated. ${ }^{89}$ However, criminalisation is not enough to achieve effective deterrence. Criminal law must be enforced in order to have a deterrence effect. In an atmosphere of impunity, legal protection of the right to life is ineffective. ${ }^{90}$

Deterrence and general prevention are considered the main rationale behind the obligations to criminalise, investigate, and prosecute, while special crime prevention and the intention to protect society from specific perpetrators are rather the exception. Special prevention appears to be the central rationale in Mastromatteo v. Italy, where the Court stated that a prison sentence has the function 'to protect society for example by preventing a criminal from re-offending and thus causing further harm. ${ }^{91}$

Deterrence considerations can also play a role when it comes to individual rights violations. In Mahmut Kaya v. Turkey, the Court held that inadequate criminal procedures in the past had perpetuated an atmosphere

85 Schabas, The European Convention on Human Rights: A Commentary (2015), $551 \mathrm{f}$.; Roberti di Sarsina, Transitional Justice and a State's Response to Mass Atrocity (2019), 78.

86 Seibert-Fohr, Prosecuting Serious Human Rights Violations (2009), 116.

87 Id., 124.

88 ECtHR, Judgment, 26 March 1985, $X$ and $Y v$ The Netherlands, Application No. $8978 / 80$, para. 27.

89 Ibid.

90 See Seibert-Fohr, Prosecuting Serious Human Rights Violations (2009), 118.

91 ECtHR, Judgment (GC), 24 October 2002, Mastromatteo v Italy, Application No. 37703/97, para. 72 . 
of impunity, and thus enabled the violation of the rights of the victim in the case at hand. ${ }^{92}$ In short, the lack of effective enforcement of existing criminal law provisions in previous cases explains why the Court found that the protection offered to the applicant was lacking. However, this rationale remains the exception, as the Court made clear that it only applies in a narrow set of circumstances. In the above case, the Court considered that a pattern of inadequate investigations and prosecutions in the past 'undermined the effectiveness of the protection afforded by the criminal law' and 'permitted or fostered a lack of accountability of members of the security forces for their actions which [...] was not compatible with the rule of law in a democratic society respecting the fundamental rights and freedoms guaranteed under the Convention. ${ }^{93}$

However, deterrence is not the only rationale behind the obligations to investigate and prosecute serious human rights violations. In some instances, the Court found that the protection of the rule of law required criminal prosecution. ${ }^{94}$ The rationale of protecting the rule of law originated from Öneryildiz v. Turkey and was confirmed in recent cases. ${ }^{95}$ In that case, the Court stated that 'the national courts should not under any circumstances be prepared to allow life-endangering offences to go unpunished. This is essential for maintaining public confidence and ensuring adherence to the rule of law and for preventing any appearance of tolerance of or collusion in unlawful acts. ${ }^{96}$ Furthermore, in analysing the

92 ECtHR, Judgment, 28 March 2000, Mahmut Kaya $v$ Turkey, Application No. 22535/93, para. 96 .

93 Id., para. 98.

94 ECtHR, Judgment, 28 January 2010, Zinatullin $v$ Russia, Application No. 10551/10, para. 37; see also ECtHR, Judgment, 30 June 2020, Satybalova and Others $v$ Russia, Application No. 79947/12, para. 71; ECtHR, Judgment, 2 April 2020, Kukhalashvili and Others $v$ Georgia, Application Nos. 8938/07, 41891/07, para. 129.

95 ECtHR, Judgment (GC), 30 November 2004, Öneryildiz v Turkey, Application No. 48939/99, para. 96; see also ECtHR, Judgment, 28 January 2010, Zinatullin $v$ Russia, Application No. 10551/10, para. 37; ECtHR, Judgment, 30 June 2020, Satybalova and Others $v$ Russia, Application No. 79947/12, para. 71; ECtHR, Judgment, 2 April 2020, Kukhalashvili and Others $v$ Georgia, Application Nos. 8938/07, 41891/07, para. 129.

96 ECtHR, Judgment (GC), 30 November 2004, Öneryildiz v Turkey, Application No. 48939/99, para. 96; see also ECtHR, Judgment, 28 January 2010, Zinatullin $v$ Russia, Application No. 10551/10, para. 37; ECtHR, Judgment, 30 June 2020, Satybalova and Others $v$ Russia, Application No. 79947/12, para. 71; ECtHR, Judgment, 2 April 2020, Kukhalashvili and Others $v$ Georgia, Application Nos. 8938/07, 41891/07, para. 129. 
requirements for an effective investigation, the Court referred to 'public confidence in the State's monopoly on the use of force. ${ }^{97}$ Where State agents are involved, the Court additionally stresses the importance of investigation to hold them accountable for deaths occurring under their responsibility. ${ }^{98}$

Seibert-Fohr observes that, although in the context of individual complaints, 'prosecution as a matter of general human rights protection as shared interest of society' is the main rationale utilised by the Court to justify the need for criminal law measures. This aligns with the trend in the Court's jurisprudence to 'use individual complaints to test compliance with the Convention more generally. 99

As anticipated, the Court has so far ruled out the existence of an individual right of a victim to have a perpetrator prosecuted or punished. ${ }^{100}$ In that regard, the ECtHR has refused to adopt the 'right to justice' doctrine developed and applied by the Inter-American Court of Human Rights. ${ }^{101}$ Nevertheless, in the jurisprudence of the ECtHR, victims are recognised to have a right to an investigation (framed as 'remedial right'), ${ }^{102}$ capable of leading to the identification and punishment of those responsible, which is generally derived from the right to a remedy enshrined in Article 13 ECHR. ${ }^{103}$ Such an investigation is a necessary precondition for the victim to obtain redress. More recently, however, there is a trend towards finding the legal basis of the obligations to investigate and prosecute in the substantive right affected, especially the right to life. ${ }^{104}$

97 ECtHR, Judgment (GC), 15 May 2007, Ramsahai and Others $v$ The Netherlands, Application No. 52391/99, para. 325.

98 ECtHR, Judgment, 4 May 2001, Hugh Jordan v The United Kingdom, Application No. 24746/94, paras. 105, 144.

99 See Seibert-Fohr, Prosecuting Serious Human Rights Violations (2009), 119.

100 See Roberti di Sarsina, Transitional Justice and a State's Response to Mass Atrocity (2019), 78.

101 See e.g. ECtHR, Judgment (GC), 26 October 1999, Erikson v Italy, Application No. 37900/97; ECtHR, Judgment (GC), 12 February 2004, Perez v France, Application No. 47287/99; ECtHR, Judgment (GC), 30 November 2004, Öneryildiz v Turkey, Application No. 48939/99, para. 96. See also Seibert-Fohr, Prosecuting Serious Human Rights Violations (2009), 123 f.; Roberti di Sarsina, Transitional Justice and a State's Response to Mass Atrocity (2019), 74.

102 Seibert-Fohr, Prosecuting Serious Human Rights Violations (2009), $124 \mathrm{ff}$.

103 See e.g. ECtHR, Judgment, 24 February 2005, Isayeva v Russia, Application No 57950/00, paras. $228 \mathrm{ff}$.; Roberti di Sarsina, Transitional Justice and a State's Response to Mass Atrocity (2019), 79.

104 Ibid., citing ECtHR, Judgment (GC), 15 May 2007, Ramsahai and Others $v$ The Netherlands, Application No. 52391/99, paras. 356, 362. 
In sum, the ECtHR has made clear that States parties have positive 'procedural' obligations to criminalise, investigate, and prosecute stemming from the substantive provisions read in conjunction with Article 1 or stemming from Article 13. It has also developed precise and strict standards for securing the implementation of these obligations, especially in its jurisprudence relating to infringements of the right to life and the prohibition of torture. The obligations to criminalise, investigate, and prosecute are mainly considered as measures of general human rights protection, which aim to guarantee non-repetition and ensure deterrence to the benefit of the society at large. However, the distinction between the concept of prevention and the concept of remedy is blurred in the jurisprudence of the Court. ${ }^{105}$ Since the concept of prevention is tied to protecting society at large and the concept of remedy is tied to the individual victim, this trend indicates an increasing conflation of individual, remedial rights and additional preventative obligations on State Parties.

\section{Conclusion}

In 2009, Anja Seibert-Fohr identified 'a trend towards gradually assuming additional criminal law obligations under the European Convention. ${ }^{106}$ It is true that - as Judge Françoise Tulkens acknowledges - a State can potentially be held accountable by the ECtHR for failures at 'each step of the criminal law process', from criminalisation of certain acts, to execution of the sentence. ${ }^{107}$ This tendency is confirmed and reinforced in the most recent jurisprudence of the Court, as it aligns with a general trend towards human rights protection through criminal law. ${ }^{108}$

Despite the legitimate concerns raised against an expansion of the ECtHR's jurisprudence regarding criminal measures and acknowledging that States Parties should retain a margin of appreciation in determining the means to secure the rights protected by the Convention, it cannot be said that the Court's increasing engagement with the procedural obligations to criminalise, investigate, and prosecute constitutes an undue restriction on a State's prerogatives. In this regard, it should be stressed that the extension of the scope of criminal law measures in the jurisprudence of the

105 Seibert-Fohr, Prosecuting Serious Human Rights Violations (2009), 149.

106 Id., 146.

107 Tulkens, 'The Paradoxical Relationship between Criminal Law and Human Rights' (2011), 9 JICJ, 577 (586f.).

108 See Seibert-Fohr, Prosecuting Serious Human Rights Violations (2009), 146. 
Court is limited to the most fundamental and basic rights, i.e. the right to life, freedom from torture, and the protection of liberty and security. The Court's willingness to scrutinise the overall administration of justice may produce overly prescriptive results, but this should not deter States Parties as they should cooperate with the Court in ensuring the rights enshrined in the ECHR, including their effective protection. However, the conflation of remedial and preventative concepts in the Court's jurisprudence is problematic. It shows that the Court has not yet reached a definitive understanding of the interplay between international human rights law and domestic criminal law. This emerges especially in cases arising from the unintentional infringements of the right to life.

\section{Bibliography}

Chevalier-Watts, Juliet: Effective Investigations under Article 2 of the European Convention on Human Rights: Securing the Right to Life or an Onerous Burden on a State?, EJIL 2010, $701 \mathrm{ff}$.

Gioia, Andrea: The Role of the European Court of Human Rights in Monitoring Compliance with Humanitarian Law in Armed Conflict, in: Ben-Naftali, Orna (ed), International Humanitarian Law and International Human Rights Law (2011), 201ff.

Jackson, Miles: Amnesties in Strasbourg, Oxf. J. Leg. Stud. 2018, 451ff.

Lazarus, Liora: Positive Obligations and Criminal Justice: Duties to Protect or Coerce?, in: Zedner, Lucia/Roberts, Julian V. (eds), Principles and Values in Criminal Law and Criminal Justice: Essays in Honour of Andrew Ashworth (2012), $135 \mathrm{ff}$.

Mallinder, Louise: Investigations, Prosecutions and Amnesties under Articles 2 \& 3 of the European Convention on Human Rights, Transitional Justice Institute, Research Paper No. 15-05 (2015), https://papers.ssrn.com/sol3/papers.cfm?abstra ct_id=2668106.

Mavronicola, Natasa: Taking Life and Liberty Seriously, MLR 2017, $1026 \mathrm{ff}$.

Roberti di Sarsina, Jacopo: Transitional Justice and a State's Response to Mass Atrocity (2019).

Schabas, William: The European Convention on Human Rights: A Commentary (2015).

Seibert-Fohr, Anja: Prosecuting Serious Human Rights Violations (2009).

Tulkens, Françoise: The Paradoxical Relationship between Criminal Law and Human Rights, JICJ 2011, 577ff. 